\title{
PENGARUH KADAR AIR DI ATAS OMC PADA TANAH EKSPANSIF TERHADAP KUAT DUKUNG TANAH DAN KEMBANG SUSUT
}

\author{
Fadel Muhammad Haykal ${ }^{1}$, Zana Hary Barus ${ }^{2}$, Sutikno Sumomihardjo ${ }^{3}$ \\ 1,2,3 Jurusan Teknik Sipil ,Politeknik Negeri Jakarta, Jl. Prof. DR. G.A. Siwabessy, Kukusan, Kecamatan \\ Beji, Kota Depok, 16424. \\ e-mail :muhammad.fadelmh7@gmail.com ${ }^{1}$,zanahary1@gmail.com²,tssumomihardjo@yahoo.com ${ }^{3}$
}

\begin{abstract}
Many regions in Indonesia have a variety of soil types, one of which is expansive soil. Expansive soil has high shrinkage to be used as one of the road construction materials. The problem that is often faced in road construction with a subgrade layer of expansive soil is the high swelling potential. This research aims to find out the soil bearing capacity of expansive soil as subgrade layer when given a variation in water content above the value of $O M C$ with 2 conditions, soaked and unsoaked. From research results it was found that the increase of water content and treatment conditions on the soil affected the soil bearing capacity of the soil, where in the unsoaked conditions, the higher the water content the greater the soil bearing capacity is. In soaked conditions, the higher the water content, the smaller the soil bearing capacity is. The higher the water content is, the smaller the swelling is.
\end{abstract}

Keywords: expansive soil, compaction, $O M C, C B R$, shear strength, swelling.

\begin{abstract}
ABSTRAK
Banyak wilayah di Indonesia yang memiliki jenis tanah yang beragam salah satunya adalah tanah ekspansif. Tanah ekspansif memiliki kembang susut yang tinggi untuk digunakan sebagai salah satu material konstruksi jalan raya. Permasalahan yang sering dihadapi pada konstruksi jalan dengan lapisan tanah dasar dari tanah ekspansif adalah potensi pengembangan (swelling) yang tinggi. Penelitian ini bertujuan untuk mengetahui kuat dukung tanah ekspansif sebagai tanah subgrade apabila diberi variasi kadar air diatas nilai OMC dengan 2 kondisi, yaitu direndam (soaked) dan tidak direndam (unsoaked). Dari hasi penelitian didapat bahwa penambahan kadar air dan kondisi perlakuan pada tanah berpengaruh terhadap kuat dukung tanah, dimana pada kondisi tidak direndam (unsoaked), semakin bertambahnya kadar air semakin besar kuat dukungnya. Pada kondisi direndam (soaked), semakin bertambahnya kadar air semakin kecil kuat dukungnya. Semakin bertambah kadar air semakin kecil pengembangannya.
\end{abstract}

Kata kunci: tanah ekspansif, pemadatan, OMC, CBR, kekuatan geser, kembang susut.

\section{PENDAHULUAN}

Beberapa dekade ini perkembangan ekonomi di Indonesia berkembang pesat terutama di daerah Cikarang sebagai salah satu daerah perindustrian terbesar di Indonesia, karena hal tersebut maka dibuatlah jaringan penghubung antara Ibukota dengan kota-kota sekitarnya terutama Cikarang yaitu peningkatan jalan raya. Banyak daerah di Indonesia yang memiliki jenis tanah yang dominan meiliki kembang susut yang tinggi untuk digunakan sebagai salah satu material konstruksi jalan raya. Salah satu sebaran tanah yang memiliki kembang susut yang tinggi (tanah ekspansif) ada di Cikarang dan sekitarnya.

Tanah ini adalah bagian dari tanah lempung yang banyak mengandung mineral yang memiliki potensi untuk mengembang atau menyusut yang cukup besar ketika mengalami perubahan kadar air. Menurut Hardiyatmo (1992) sifatsifat yang dimiliki dari tanah lempung 
yaitu antara lain ukuran butiran halus lebih kecil dari 0,002 mm, permeabilitas rendah, kenaikan air kapiler tinggi, bersifat sangat kohesif, kadar kembang susut yang tinggi dan proses konsolidasi lambat. Tanah ekspansif adalah tanah yang memiliki sifat mengembang dan menyusut yang tinggi karena pengaruh kadar air didalamnya. Permasalahan yang sering dihadapi pada konstruksi jalan diatas tanah ekspansif adalah daya dukung yang rendah dan potensi pengembangan yang tinggi.

Berdasarkan hal tersebut penulis ingin mengetahui bagaimana karakteristik tanah ekspansif (expansive soil) jika diberi kadar air diatas nilai kadar air optimum/optimum moisture content (OMC) terhadap kuat dukung tanah. Mayasari (2008) telah melakukan penelitian tentang pengaruh variasi kadar air terhadap potensi dan tekanan pengembangan tanah ekspansif di bandara Lombok Baru. Penelitian dari Yuliani (2008) menyatakan bahwa pada areal wilayah desa Penujak, sebagian tanah terdiri dari lempung hitam. Jenis ini memiliki sifat mengembang (swelling) pada musim hujan dan menyusut pada musim kemarau. Sedangkan Waskito Aji (2012) menyatakan bahwa semakin besar kadar air pada tanah ekspansif semakin kecil tekanan pengembangannya. Terakhir, pada penelitiannya, Ratna (2012) mengatakan bahwa semakin tinggi kadar air pada tanah ekspansif yang terendam semakin kecil pula nilai CBR dan pengembangannya. Penelitian tentang perilaku tanah ekspansif pada daerah sekitar LIPPO Cikarang masih jarang dilakukan, oleh karena itu penelitian ini diharapkan dapat mengetahui karakteristik tanah pada daerah tersebut.

\section{METODE PENELITIAN}

Penelitian ini merupakan penelitian eksperimental laboratorium. Semua data yang dibutuhkan adalah data primer.
Benda uji tanah didapatkan dari lokasi studi kasus yakni dari daerah LIPPO Cikarang, lebih tepatnya di Jl. Cibatu, Cikarang, Jawa Barat. Bagan alir tahapan pelaksanan penelitian secara runtut dapat dilihat pada Gambar 1. Semua tahapan pengujian dilaksanakan di Laboratorium Mekanika Tanah, Jurusan Teknik Sipil, Politeknik Negeri Jakarta.

\section{Bagan Alir Penelitian}

Alur penelitian dapat dilihat pada Gambar 1.

\section{Bahan}

Bahan yang digunakan pada penelitian ini yaitu tanah asli dari daerah Cibatu, Cikarang dan air.

\section{Pengujian Material}

1. Uji Dasar

Sebelum melakukan penelitian, dilakukan uji dasar telebih dahulu terhadap tanah yang digunakan. Berikut metode pengujian sifat fisik dan mekanis tanah :

a. Pemeriksaan berat jenis tanah (ASTM D-854-02)

b. Pemeriksaan batas konsistensi (atterberg limits) (ASTM D-431895)

c. Kadar air tanah asli (ASTM D2216-98)

d. Pemeriksaan analisis distribusi ukuran butir (ASTM D-4318-95) dan hydrometer (ASTM D-44298)

e. Kepadatan standard (ASTM D698-12)

f. Uji CBR (ASTM D-1883-99)

g. Uji kuat geser langsung (direct shear strength) (ASTM D-216616)

h. Uji pengembangan tanah (swelling) (ASTM D-4546-90)

2. Uji Perilaku
a. Variasi kadar air
b. Variasi kondisi tanah (direndam dan tidak direndam) 


\section{Variabel penelitian}

Variabel dalam penelitian berikut adalah sebagai berikut:

a) Variabel bebas dalam penelitian ini antara lain:

1) Penambahan air yang digunakan

2) Kondisi tanah (tidak direndam dan direndam)

3) Lama perendaman

4) Jumlah pukulan

b) Variabel terikat dalam penelitian ini antara lain:

1) Daya dukung tanah

2) Kekuatan geser tanah

3) Pengembangan (swelling) yang terjadi pada tanah

\section{HASIL dan PEMBAHASAN}

\section{A. Sifat Fisik Tanah}

1. Berat Jenis (Specific Gravity)

Dari hasil percobaan di laboratorium, didapat nilai berat jenis rata-rata asli sebesar 2,58 (dapat dilihat pada Tabel 1). Menurut SNI 1964: 2008 berat jenis untuk tanah lempung berkisar antara 2,58 - 2,75. Jadi, tanah yang diuji tergolong tanah lempung.

2. Batas Konsistensi (Atterberg Limits)

a. Batas Cair

Pada ketukan ke-25 diketahui kadar airnya adalah sebesar $78,47 \%$, sehingga nilai batas cairnya (liquid limit) sebesar $78,47 \%$ (dapat dilihat pada Tabel 2).

b. Batas Plastis

Nilai batas plastis didapat dari kadar air rata-rata pada tanah uji yang dibentuk batang dengan diameter sebesar $3 \mathrm{~mm}$. Didapat nilai kadar air rata-rata dari 3 sampel uji sebesar 24,03\% (dapat dilihat pada Tabel 3). c. Indeks Plastis

Nilai indeks plastisitas (PI) didapat dari selisih antara nilai batas cair (LL) dengan nilai batas plastis (PL). $\mathrm{PI}=54,44 \%$.

3. Klasifikasi Tanah

a. Berdasarkan USCS

Tanah yang lolos saringan No.200 (0,075 mm) didapat sebesar 70,20\%, tanah yang diuji termasuk tanah butiran halus dengan plastisitas tinggi (H). Dari bagan plastisitas, nilai indeks plastisitas (PI) dan batas plastis (LL) digunakan untuk mengklasifikasikan tanah yang diuji. Diperoleh klasifikasi tanah uji tergolong $\mathrm{CH}$ (Clay High Plasticity) yaitu lempung tak organik dengan plastisitas tinggi atau lempung "gemuk" (fat clays).

b. Berdasarkan AASHTO

Besar nilai LL \& PI

$\mathrm{LL} \quad=78,47 \%$

PI $=54,44 \%$

*PI > LL-30

$54,44>48,47$

Tanah tersebut termasuk kedalam kelompok A-7-6 yaitu tanah berlempung dimana tanah jenis ini kurang baik digunakan sebagai lapisan tanah dasar (subgrade) konstruksi jalan.

Berdasarkan nilai indeks grup (GI) adalah,

$\mathrm{GI}=3,645 \approx 4$

Tanah yang diuji diklasifikasikan sebagai A-76(4), menurut AASHTO tanah yang diuji termasuk kedalam kelompok tanah yang buruk sehingga kurang baik digunakan sebagai lapisan 
tanah dasar (subgrade)

konstruksi jalan dan harus dilakukan perbaikan sifat fisik dan mekanisnya agar layak digunakan sebagai lapisan tanah dasar (subgrade).

\section{Ukuran Butir}

a. Analisa Saringan

Berdasarkan hasil analisa saringan (dapat dilihat pada

Tabel 4) yang telah dilakukan tanah tersebut terdiri atas beberapa macam ukuran dan dikelompokan berdasarkan ukuran butirannya, sebagai berikut:

$\begin{array}{ll}\text { Kerikil } & : 0 \% \\ \text { Pasir } & : 29,80 \% \\ \text { Lanau } & : 25,91 \% \\ \text { Lempung } & : 44,29 \%\end{array}$

b. Analisa Hydrometer

Dari hasil analisa, presentase tanah berbutir halus lebih banyak, yaitu sebesar 44,29\%. Sehingga tanah yang diuji termasuk tanah berbutir halus. Syarat tanah dikatakan memiliki keseragaman yang baik bila nilai $\mathrm{Cu}>15$. Tanah yang diuji tergolong memiliki keseragaman yang baik karena diperoleh nilai $\mathrm{Cu}=47,37$ (dapat dilihat pada Tabel 5).

\section{B. Sifat Mekanis Tanah}

1. Aktivitas Tanah

Tanah dengan nilai PI > 35 dan LL $>63$ merupakan tanah lempung yang memiliki potensi pengembangan (swelling) yang tinggi. Untuk mencari nilai aktivitas tanah lempung dapat digunakan rumus Skempton

Aktivitas $=1,583$

Dengan nilai aktivitas sebesar 1,583 , jenis mineral yang paling dominan terkandung dalam tanah uji adalah Montmorillonite.
2. Pemadatan Standar

Nilai kadar air optimum ( $\omega$ opt) didapat dengan menghubungkan nilai berat isi kering maksimum ( $\gamma d$ max) dengan nilai kadar air $(\omega)$ pada grafik hubungan seperti Gambar 2.

Dari kurva tersebut dapat diketahui nilai kadar air optimum $(\omega$ opt) yang didapat yaitu sebesar $18,05 \%$ dengan berat isi kering maksimum ( $\gamma \mathrm{d} \max ) 1,579 \mathrm{gr} / \mathrm{cm} 3$ dan berat isi kering zavc ( $\gamma \mathrm{d}$ zavc) sebesar 1,758 gr/cm3 (dapat dilihat pada Tabel 6).

3. CBR Laboratorium

Pada pengujian ini benda uji yang dibuat sebanyak 6 (enam) buah, yaitu tanah uji dengan penambahan air $21 \%$ (soaked dan unsoaked), tanah uji dengan penambahan air 23\% (soaked dan unsoaked), dan tanah uji dengan penambahan air 25\% (soaked dan unsoaked). Dari enam kondisi tersebut dibuatlah resume nilai CBR dan korelasi antara nilai CBR dengan kadar airnya berdasarkan kondisinya (soaked dan unsoaked) yang dapat dilihat pada Tabel 7, Gambar 5 dan Gambar 6.

Tanah pada kondisi kering (unsoaked) memiliki nilai CBR yang lebih tinggi dibandingkan tanah pada kondisi basah (soaked). Hal tersebut disebabkan tanah sampai pada titik jenuhnya sehingga mengalami penurunan kekuatan. Pada kondisi kering (unsoaked) kurva berbentuk cekung dengan nilai CBR tertinggi pada kadar air 27,624\% dengan nilai $7,12 \%$. Sedangkan pada kondisi basah (soaked) berkebalikan dengan kondisi kering, dimana kurva berbentuk cembung dengan nilai CBR tertinggi pada kadar air $34,836 \%$ dengan nilai $5,13 \%$. 
4. Geser Langsung

Berdasarkan Tabel 8, Gambar 7 dan Gambar 8, tanah dalam kondisi kering (unsoaked) nilai kohesi (c) dan sudut geser dalam (Ø) mengalami penurunan dibanding tanah dengan kadar air yang paling sedikit diantara ketiga benda uji $(32,063 \%)$. Sedangkan pada Tabel 9, Gambar 9 dan Gambar 10, tanah kondisi basah (soaked), nilai kohesi (c) sudut geser dalam (Ø) mengalami penurunan dibanding tanah dengan kadar air terkecil diantara ketiga benda uji $(32,063 \%)$.

5. Pengembangan Tanah (swelling) Berdasarkan Gambar 11, pada hari keenam mengalami penurunan dibanding tanah dengan kadar air terkecil $(32,063 \%)$. Hal tersebut berarti semakin besar kadar air yang diberikan, semakin kecil pengembangan (swelling) yang terjadi.

\section{KESIMPULAN}

Dari hasil penelitian yang telah penulis lakukan, maka dapat disimpulkan sebagai berikut:

1. Berdasarkan metode USCS maka diperoleh tanah ekspansif di daerah Cibatu, Cikarang termasuk kelompok $\mathrm{CH}$ yaitu Lempung Anorganik dengan plastisitas tinggi (LL > 50). Sedangkan berdasarkan metode AASHTO tanah tersebut termasuk kedalam kelompok A-7-6 yaitu tanah berlempung dengan nilai $\mathrm{GI}=4$ yaitu tanah yang kurang baik jika digunakan sebagai lapisan subgrade,

2. Penambahan kadar air dan kondisi perlakuan pada tanah berpengaruh terhadap kuat dukung tanah, dimana pada kondisi tidak direndam (unsoaked), semakin bertambahnya kadar air semakin besar kuat dukungnya. Pada kondisi direndam (soaked), semakin bertambahnya kadar air semakin kecil kuat dukungnya,

3. Penambahan kadar air dapat menurunkan nilai kohesi (c) dan sudut geser dalam (Ø) dibanding tanah dengan kadar air terkecil,

4. Besarnya kadar air berpengaruh terhadap nilai pengembangan (swelling), dimana semakin besar kadar air maka semakin kecil nilai pengembangan (swelling) tanah uji.

\section{DAFTAR PUSTAKA}

[1] Skempton, 1953, The Colloidal Activity of Clays Procceding 3 th International Conference of Soil Mechanic and Fondation Engineering, London.Christady Hardiyatmo, Hary. 1992, Mekanikia Tanah 1. Jakarta: Gramedia,

[2] Seed, M. B., Woodward, R.J. and Lundgren, R., 1962. Prediction of Swelling Potensial of compacted soils. ASCE Journal of Soil Mechanics and Foundation Engineering.

[3] Bowles, J.E., 1989, Sifat-sifat fisik dan Geoteksnis Tanah (Mekanika Tanah), Jakarta: Erlangga.

[4] Christady Hardiyatmo, Hary. 1992, Mekanikia Tanah 1. Jakarta: Gramedia,

[5] M.Das, Braja,1995 Mekanika Tanah (Prinsip-prinsip Rekayasa Geoteknis) Jilid 1. Jakarta: Erlangga.

[6] Mayasari, D., 2008, Pengaruh Variasi Kadar Air Terhadap Potensi dan Tekanan Pengembangan Tanah Lempung Ekspansif Bandara Lombok Baru dengan Oedometer, Skripsi, Jurusan Teknik Sipil, FT. UNRAM. 
[7] Yuliani, D.I., 2008, Identifikasi Potensi dan Tekanan Pengembangan Tanah Lempung Ekspansif Bandara Lombok Baru dengan Oedometer, Skripsi, Jurusan Teknik Sipil, FT. UNRAM.

[8] Waskito Aji, Wahyudi, 2012, Uji Tekanan Pengembangan Tanah Ekspansif Ditinjau Dari Besarnya
Kadar Air, Skripsi, Jurusan Teknik Sipil, FT. UNS.

[9] Ratna, Dwi F., 2012, Pengaruh Variasi Kadar Air Terhadap Perkembangan dan Daya Dukung Tanah Ekspansif di Kecamatan Paron Kabupaten Ngawi, Skripsi, Jurusan Teknik Sipil, FT. UNIBRAW.

\section{Lampiran Tabel dan Gambar}

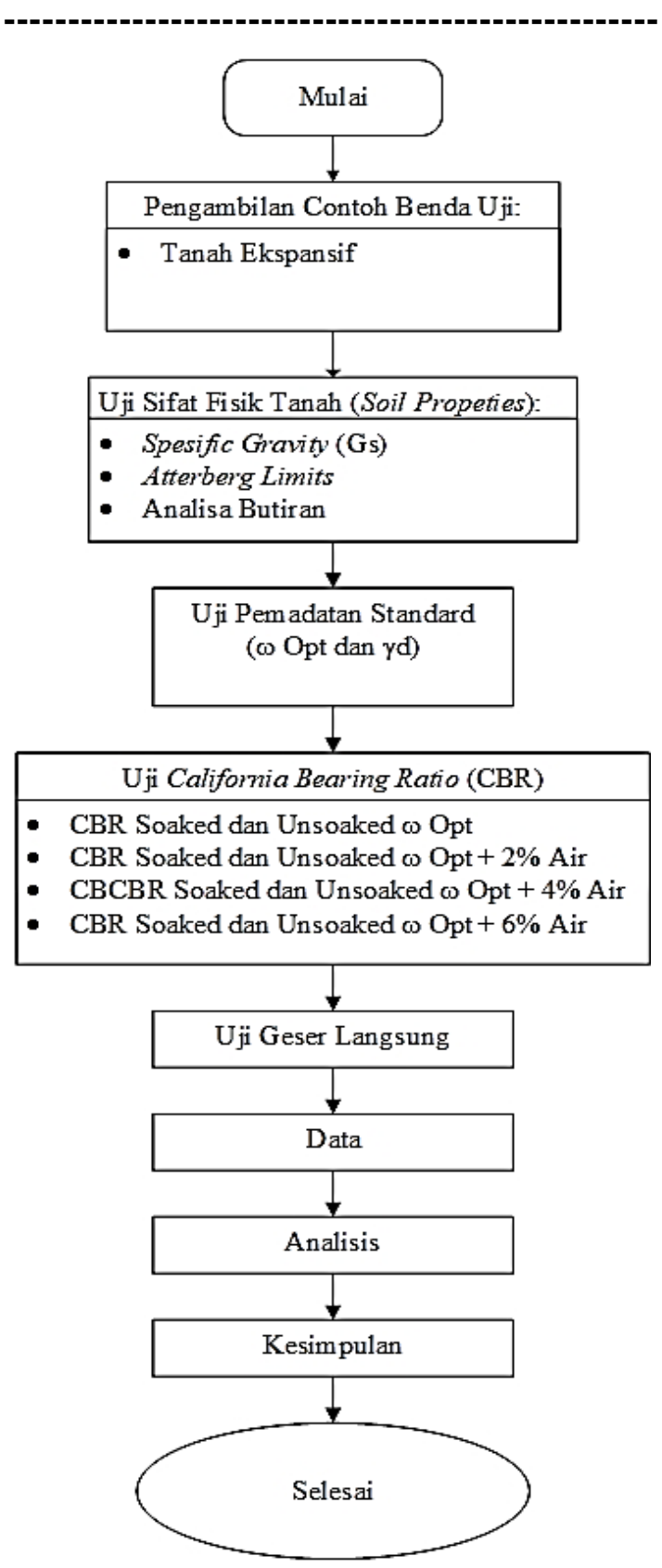

Gambar 1. Diagram Alir Penelitian 
Tabel 1. Hasil pengujian berat jenis

\begin{tabular}{|c|l|c|c|c|}
\hline \multirow{2}{*}{ No Uraian } & \multicolumn{3}{|c|}{ Nomer Pengujian } \\
\cline { 3 - 5 } & & 34 & 10 & 16 \\
\hline 1 & Berat Piknometer Kosong + Tutup (m1) & 21,2 & 35,7 & 26,4 \\
\hline 2 & Berat Piknometer + Tutup + Contoh Tanah (m2) & 29,8 & 43,9 & 33,4 \\
\hline 3 & Berat Piknometer + Tutup + Contoh Tanah + Air (m3) & 76 & 89,5 & 80,5 \\
\hline 4 & Temperatur Contoh Tanah + Air (Ti) & 31 & 31 & 31 \\
\hline 5 & Faktor Koreksi & 0,9976 & 0,9976 & 0,9976 \\
\hline 6 & Berat Piknometer + Tutup + Air & 70,7 & 84,5 & 76,2 \\
\hline 7 & Temperatur Air & 32 & 32 & 32 \\
\hline 8 & Faktor Koreksi & 0,9976 & 0,9976 & 0,9976 \\
\hline 9 & Gs Gs Rata - Rata & 2,600 & 2,556 & 2,586 \\
\hline \multicolumn{2}{|r|}{} \\
\hline
\end{tabular}

Tabel 2. Hasil pengujian batas cair

\begin{tabular}{|c|c|c|c|c|c|c|c|c|c|}
\hline Jumlah Ketukan & (N) & \multicolumn{2}{|c|}{18} & \multicolumn{2}{|c|}{22} & \multicolumn{2}{|c|}{25} & \multicolumn{2}{|c|}{28} \\
\hline No. Cawan & & 110 & 78 & 64 & 28 & 84 & 11 & 122 & 66 \\
\hline Berat Cawan & (gr) & 48,3 & 49,1 & 49,6 & 53 & 47,4 & 49,4 & 47,3 & 46 \\
\hline Berat Cawan + Tanah Basah & (gr) & 58,1 & 63,1 & 57,1 & 60,3 & 55,6 & 59,8 & 63,4 & 57,9 \\
\hline Berat Cawan + Tanah Kering & (gr) & 53,8 & 56,9 & 53,8 & 57,1 & 52 & 55,2 & 56,3 & 52,7 \\
\hline Berat Air & (gr) & 4,3 & 6,2 & 3,3 & 3,2 & 3,6 & 4,6 & 7,1 & 5,2 \\
\hline Berat Tanah Kering & (gr) & 5,5 & 7,8 & 4,2 & 4,1 & 4,6 & 5,8 & 9 & 6,7 \\
\hline Kadar Air & (\%) & 78,18 & 79,49 & 78,57 & 78,05 & 78,26 & 79,31 & 78,89 & 77,61 \\
\hline Kadar Air Rata Rata & (\%) & \multicolumn{2}{|c|}{78,83} & \multicolumn{2}{|c|}{78,31} & \multicolumn{2}{|c|}{78,79} & \multicolumn{2}{|c|}{78,25} \\
\hline
\end{tabular}

Tabel 3. Hasil pengujian batas plastis

\begin{tabular}{|c|lc|c|c|c|}
\hline \multirow{2}{*}{ No } & \multirow{2}{*}{ Uraian } & \multicolumn{3}{|c|}{ Nomor Cawan } \\
\cline { 4 - 6 } & & 1 & 2 & 3 \\
\hline 1 & No. Cawan & 95 & 123 & 121 \\
\hline 2 & Berat Cawan & $(\mathrm{gr})$ & 49,4 & 49,5 & 49,1 \\
\hline 3 & Berat Cawan + Tanah Basah & $(\mathrm{gr})$ & 51,9 & 53,6 & 53,4 \\
\hline 4 & Berat Cawan + Tanah Kering & $(\mathrm{gr})$ & 51,4 & 52,8 & 52,6 \\
\hline 5 & Berat Air & $(\mathrm{gr})$ & 0,5 & 0,8 & 0,8 \\
\hline 6 & Berat Tanah Kering & $(\mathrm{gr})$ & 2 & 3,3 & 3,5 \\
\hline 7 & Kadar Air & $(\%)$ & 25,00 & 24,24 & 22,86 \\
\hline 8 & Kadar Air Rata - Rata & $(\%)$ & \multicolumn{3}{|c}{24,03} \\
\hline
\end{tabular}

Tabel 4. Hasil pengujian analisa saringan

\begin{tabular}{|c|c|c|c|c|c|c|c|}
\hline $\begin{array}{c}\text { No. } \\
\text { Saringan } \\
\end{array}$ & $\begin{array}{c}\begin{array}{c}\text { Diameter } \\
(\mathrm{mm})\end{array} \\
\end{array}$ & $\begin{array}{c}\text { Berat } \\
\text { Ayakan }\end{array}$ & $\begin{array}{c}\text { Berat Ayakan + } \\
\text { Tanah (gr) }\end{array}$ & $\begin{array}{l}\text { Berat Tertahan } \\
\text { (gr) }\end{array}$ & $\begin{array}{c}\% \\
\text { Tertahan }\end{array}$ & $\begin{array}{c}\% \\
\text { Tertahan }\end{array}$ & \% Lolos \\
\hline 4 & \begin{tabular}{|l|}
4.75 \\
\end{tabular} & 436 & 436 & 0 & 0.00 & 0.00 & 100.00 \\
\hline 10 & 2.00 & 403 & 414 & 11 & 2.20 & 2.20 & 97.80 \\
\hline 20 & 0.840 & 348 & 361 & 13 & 2.60 & 4.80 & 95.20 \\
\hline 40 & 0.425 & 317 & 342 & 25 & 5.00 & 9.80 & 90.20 \\
\hline 60 & 0.250 & 297 & 329 & 32 & 6.40 & 16.20 & 83.80 \\
\hline 100 & 0.150 & 371 & 426 & 55 & 11.00 & 27.20 & 72.80 \\
\hline 200 & 0.075 & 267 & 280 & 13 & 2.60 & 29.80 & 70.20 \\
\hline pan & --- & 442 & 442 & 0 & 0.00 & 29.80 & 70.20 \\
\hline \multicolumn{2}{|c|}{ JUMLAH } & 2881 & 3030 & 149 & 29.80 & & \\
\hline
\end{tabular}


Tabel 5. Hasil pengujian analisa hydrometer

\begin{tabular}{|c|c|c|c|c|c|c|c|c|c|c|c|}
\hline $\begin{array}{c}\text { Waktu } \\
\text { (menit) }\end{array}$ & $\begin{array}{c}\text { Temperatur } \\
{ }^{\circ} \mathrm{C}\end{array}$ & $\mathrm{Ct}$ & Ra & Rc & \% Lolos & $\begin{array}{c}\text { R Koreksi } \\
\text { Menicus }\end{array}$ & $\mathrm{L}$ & $\mathrm{L} / \mathrm{t}$ & $\mathrm{K}$ & D (mm) & $\begin{array}{c}\text { \%Lolos yang } \\
\text { diperhitungkan }\end{array}$ \\
\hline 1 & 30 & 3.8 & 48 & 48.8 & 99.16 & 49 & 8.4 & 8.4 & 0.0125 & 0.036 & 69.61 \\
\hline 2 & 30 & 3.8 & 46 & 46.8 & 95.10 & 47 & 8.6 & 4.3 & 0.0125 & 0.026 & 66.76 \\
\hline 3 & 30 & 3.8 & 45.5 & 46.3 & 94.08 & 46.5 & 8.7 & 2.9 & 0.0125 & 0.021 & 66.05 \\
\hline 4 & 30 & 3.8 & 45 & 45.8 & 93.07 & 46 & 8.8 & 2.2 & 0.0125 & 0.019 & 65.33 \\
\hline 8 & 30 & 3.8 & 44 & 44.8 & 91.03 & 45 & 8.9 & 1.11 & 0.0125 & 0.013 & 63.91 \\
\hline 15 & 30 & 3.8 & 42 & 42.8 & 86.97 & 43 & 9.2 & 0.61 & 0.0125 & 0.010 & 61.05 \\
\hline 30 & 29 & 3.05 & 40 & 40.05 & 81.38 & 41 & 9.6 & 0.32 & 0.0126 & 0.007 & 57.13 \\
\hline 60 & 29 & 3.05 & 38 & 38.05 & 77.32 & 39 & 9.9 & 0.17 & 0.0126 & 0.005 & 54.28 \\
\hline 120 & 29 & 3.05 & 35 & 35.05 & 71.22 & 36 & 10.4 & 0.09 & 0.0126 & 0.004 & 50.00 \\
\hline 240 & 29 & 3.05 & 32 & 32.05 & 65.13 & 33 & 10.9 & 0.05 & 0.0126 & 0.003 & 45.72 \\
\hline 480 & 29 & 3.05 & 31 & 31.05 & 63.09 & 32 & 11.1 & 0.02 & 0.0126 & 0.002 & 44.29 \\
\hline 960 & 28 & 2.5 & 30 & 29.5 & 59.94 & 31 & 11.2 & 0.01 & 0.0127 & 0.001 & 42.08 \\
\hline
\end{tabular}

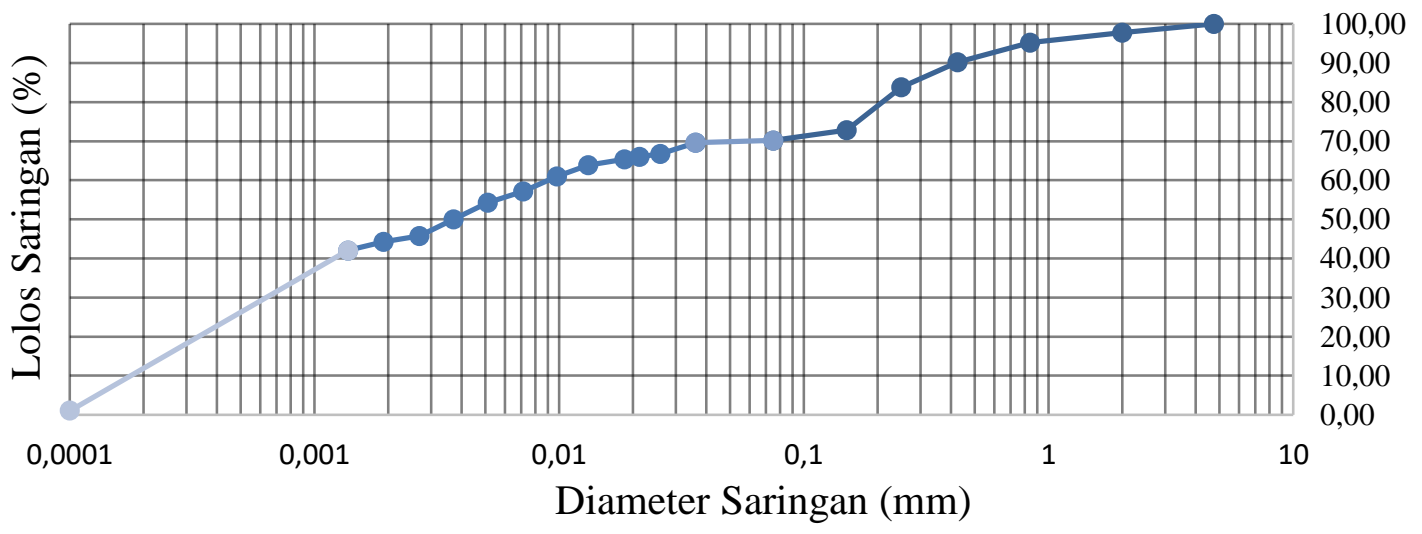

Gambar 2. Distribusi ukuran butir

Tabel 6. Hasil analisa berat volume uji pemadatan standar

\begin{tabular}{|c|c|c|c|c|c|c|}
\hline Asumsi Penambahan Air & $\%$ & $4 \%$ & $6 \%$ & $8 \%$ & $10 \%$ & $12 \%$ \\
\hline Kadar Air $(\omega)$ & $\%$ & 15,50 & 16,09 & 16,23 & 18,39 & 19,92 \\
\hline Berat Cetakan (W1) & $\mathrm{gr}$ & 4358 & 4358 & 4358 & 4358 & 4358 \\
\hline Berat Cetakan + Tanah (W2) & gr & 6122 & 6141 & 6145 & 6241 & 6212 \\
\hline Berat Tanah (W2-W1) & gr & 1764 & 1783 & 1787 & 1883 & 1854 \\
\hline Berat Isi Basah, ym & $\mathrm{gr} / \mathrm{cm}^{3}$ & 1,78 & 1,79 & 1,80 & 1,90 & 1,87 \\
\hline Berat Isi Kering, yd & $\mathrm{gr} / \mathrm{cm}^{3}$ & 1,54 & 1,55 & 1,55 & 1,60 & 1,56 \\
\hline Berat Isi zavc & $\mathrm{gr} / \mathrm{cm}^{3}$ & 1,838 & 1,818 & 1,813 & 1,745 & 1,700 \\
\hline
\end{tabular}




\begin{tabular}{|c|l|l}
\hline CM/ & $\begin{array}{l}\text { Construction and Material Journal } \\
\text { e-ISSN 2655-9625, http://jurnal.pnj.ac.id/index.php/cmi }\end{array}$ & $\begin{array}{l}\text { Volume 3 No.2 } \\
\text { Juli 2021 }\end{array}$ \\
\hline
\end{tabular}

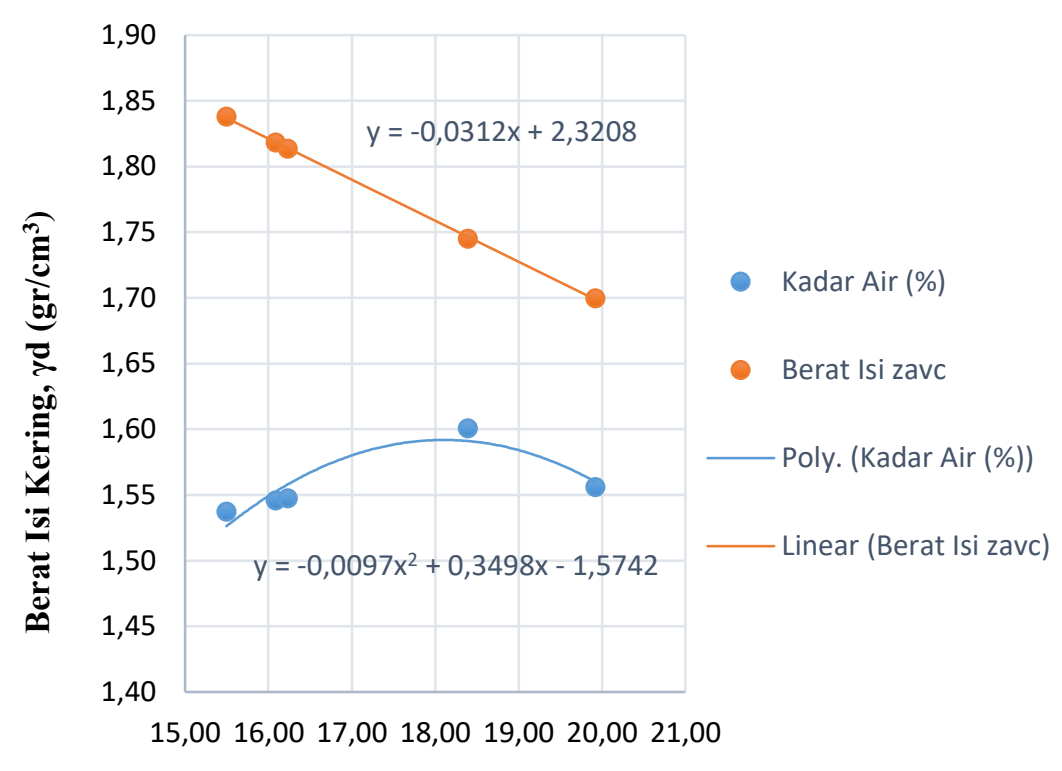

Kadar Air, $\omega(\%)$

Gambar 3. Grafik hubungan kadar air dengan berat isi kering

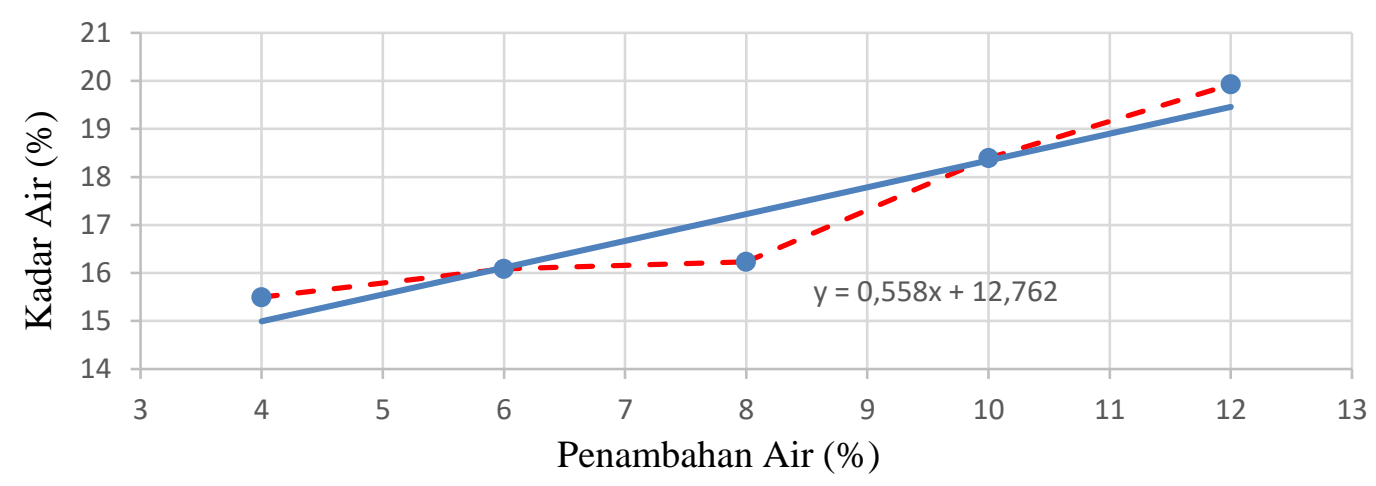

Gambar 4. Grafik perbandingan kadar air dengan penambahan air

Tabel 7. Perhitungan penambahan air terhadap kadar air

\begin{tabular}{llll}
\hline Penambahan Air (\%) & 21 & 23 & 25 \\
Kadar Air (\%) & 24,48 & 25,596 & 26,712 \\
\hline
\end{tabular}

Tabel 8. Resume nilai CBR tanah uji terhadap kadar air

\begin{tabular}{|c|c|c|c|}
\hline \multicolumn{2}{|c|}{ Kadar Air (\%) } & \multicolumn{2}{|l|}{ CBR } \\
\hline Unsoaked & Soaked & Unsoaked & Soaked \\
\hline 24,299 & 32,063 & 6,83 & 4,15 \\
\hline 25,431 & 34,836 & 4,38 & 5,13 \\
\hline 27,624 & 35,913 & 7,12 & 2,22 \\
\hline
\end{tabular}




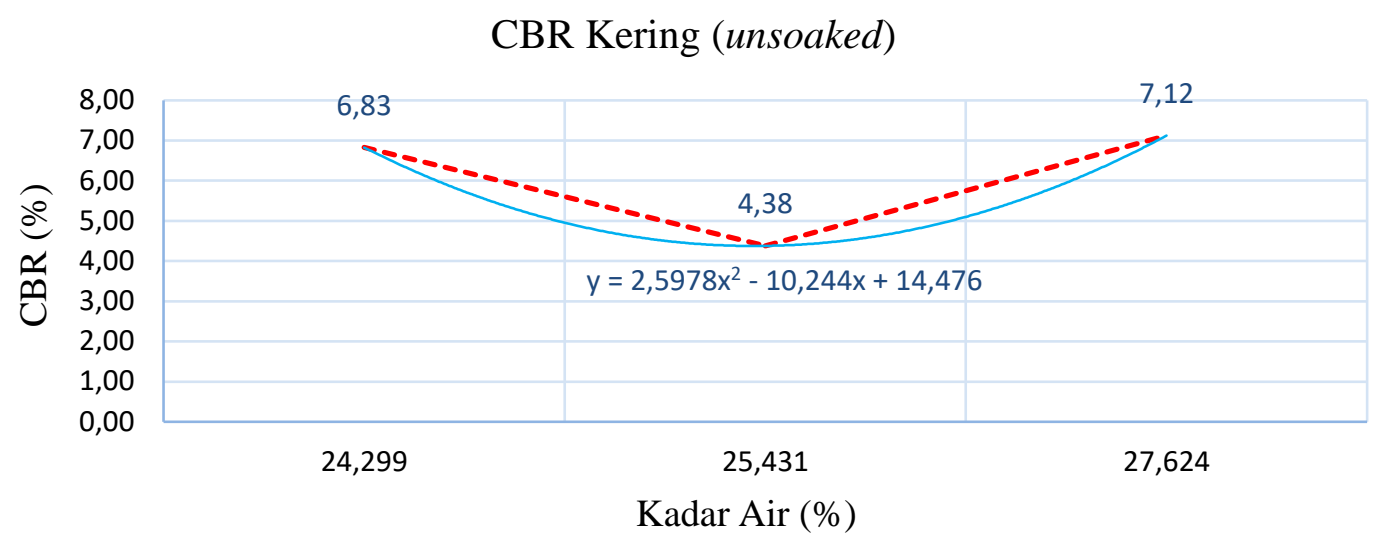

Gambar 5. Perbandingan variasi kadar air $\mathrm{CBR}_{\text {Unsoaked }}$ terhadap kadar air

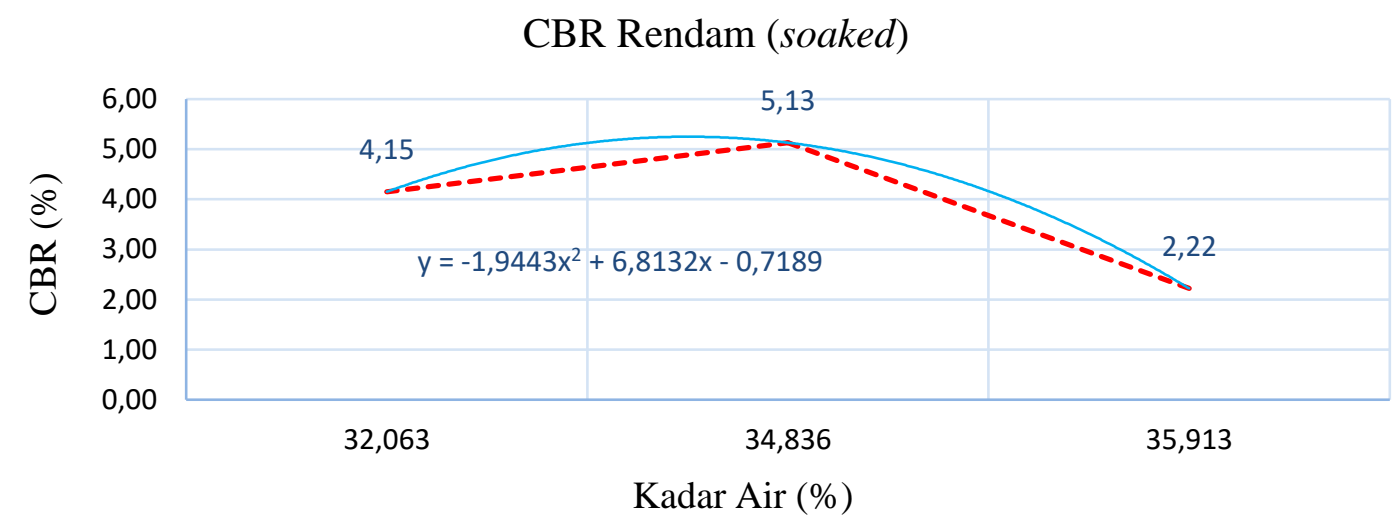

Gambar 6. Perbandingan variasi kadar air $\mathrm{CBR}_{\text {Soaked }}$ terhadap kadar air

Tabel 9. Nilai c dan $\varnothing$ pada kondisi unsoaked

\begin{tabular}{lll}
\hline \multirow{2}{*}{ Kadar Air (\%) } & \multicolumn{2}{c}{ Unsoaked } \\
& $\mathrm{c}$ & $\emptyset$ \\
$\left(\mathrm{gr} / \mathrm{cm}^{2}\right)$ & $\left(^{\circ}\right)$ \\
\hline 24,299 & 0,1401 & 25 \\
25,431 & 0,0728 & 24 \\
27,624 & 0,0897 & 21 \\
\hline
\end{tabular}

Tabel 10. Nilai c dan $\varnothing$ pada kondisi soaked

\begin{tabular}{lll}
\hline \multirow{2}{*}{ Kadar Air (\%) } & \multicolumn{2}{c}{ Soaked } \\
& c & $\emptyset$ \\
& $\left(\mathrm{gr} / \mathrm{cm}^{2}\right)$ & $\left({ }^{\circ}\right)$ \\
\hline 32,063 & 0.0548 & 26 \\
34.836 & 0.1718 & 16 \\
35,913 & 0.0613 & 24 \\
\hline
\end{tabular}




\begin{tabular}{|c|c|c|}
\hline CaMm产 & $\begin{array}{l}\text { Construction and Material Journal } \\
\text { e-ISSN 2655-9625, http://jurnal.pnj.ac.id/index.php/cmi }\end{array}$ & $\begin{array}{l}\text { Volume } 3 \text { No. } 2 \\
\text { Juli } 2021\end{array}$ \\
\hline
\end{tabular}

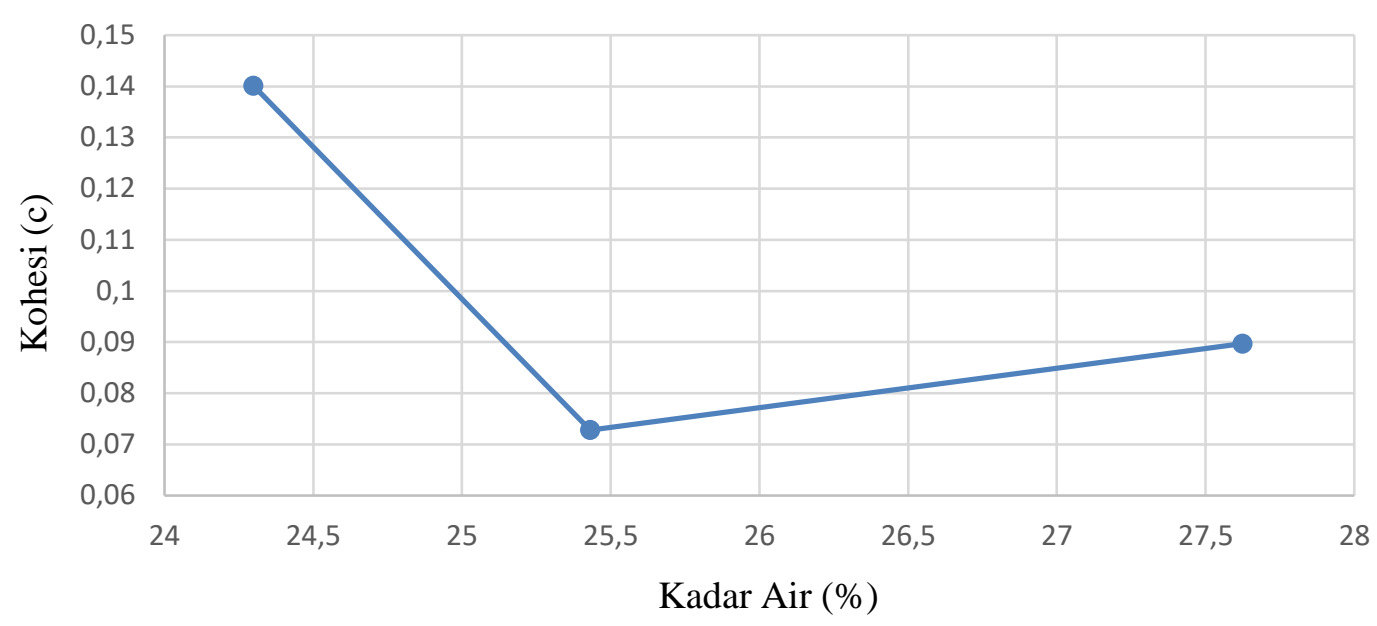

Gambar 7. Grafik hubungan kadar air dengan kohesi tanah kondisi unsoaked

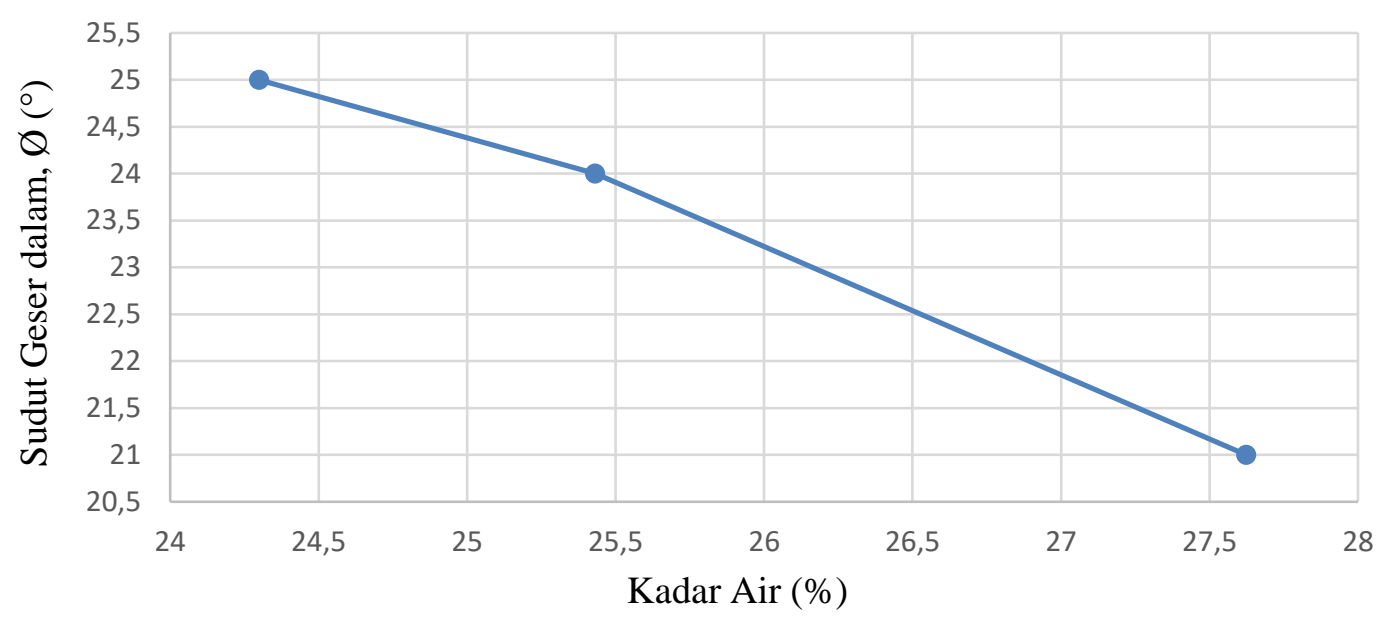

Gambar 8. Grafik hubungan kadar air dengan $\emptyset$ kondisi unsoaked

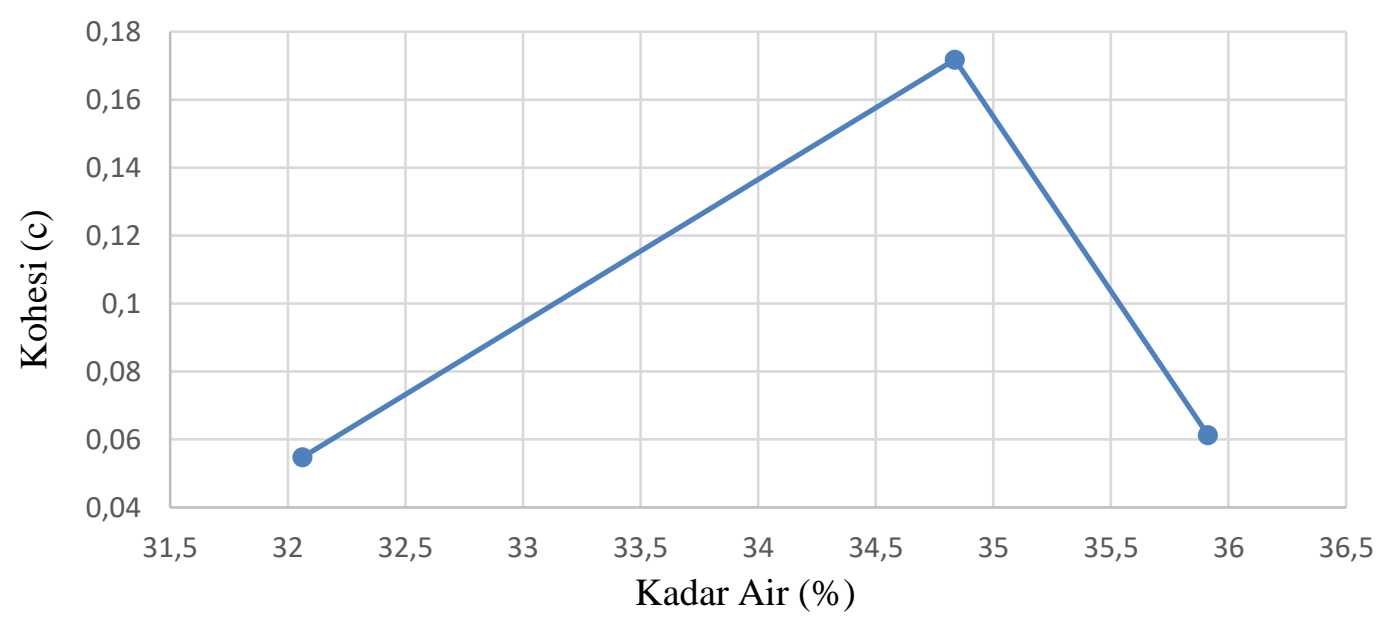

Gambar 9. Grafik hubungan kadar air dengan kohesi tanah kondisi soaked 


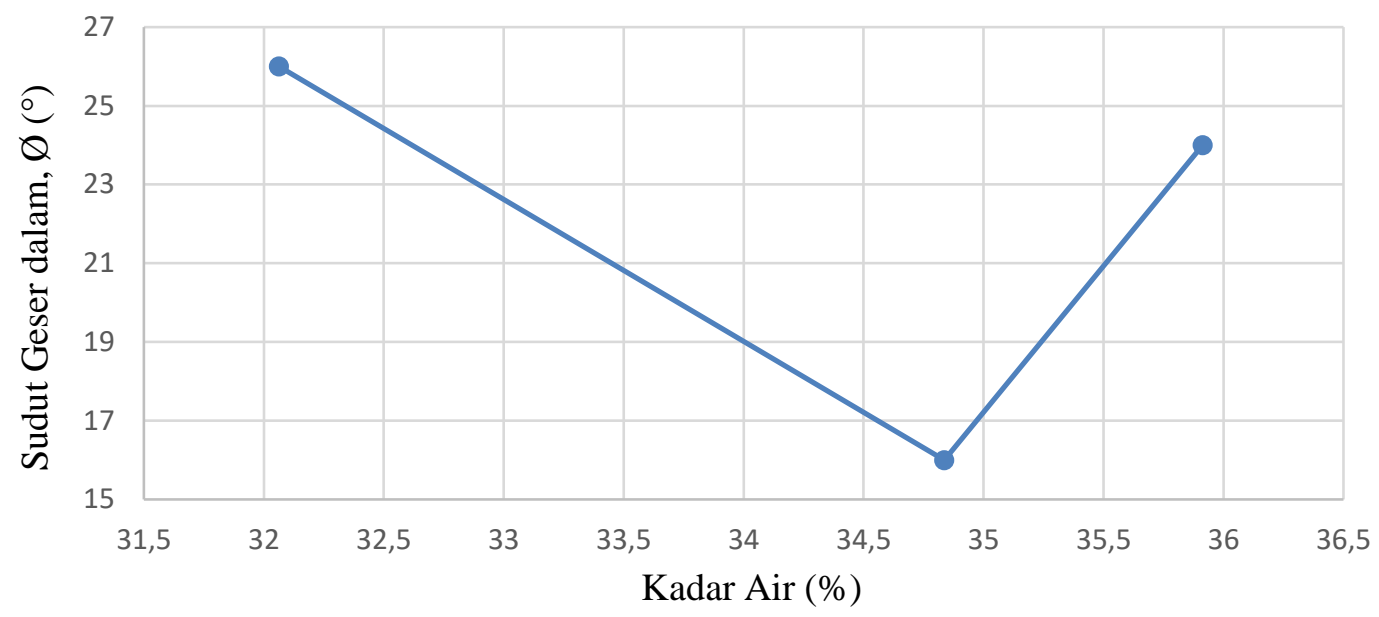

Gambar 10. Hubungan kadar air dengan $\emptyset$ kondisi soaked

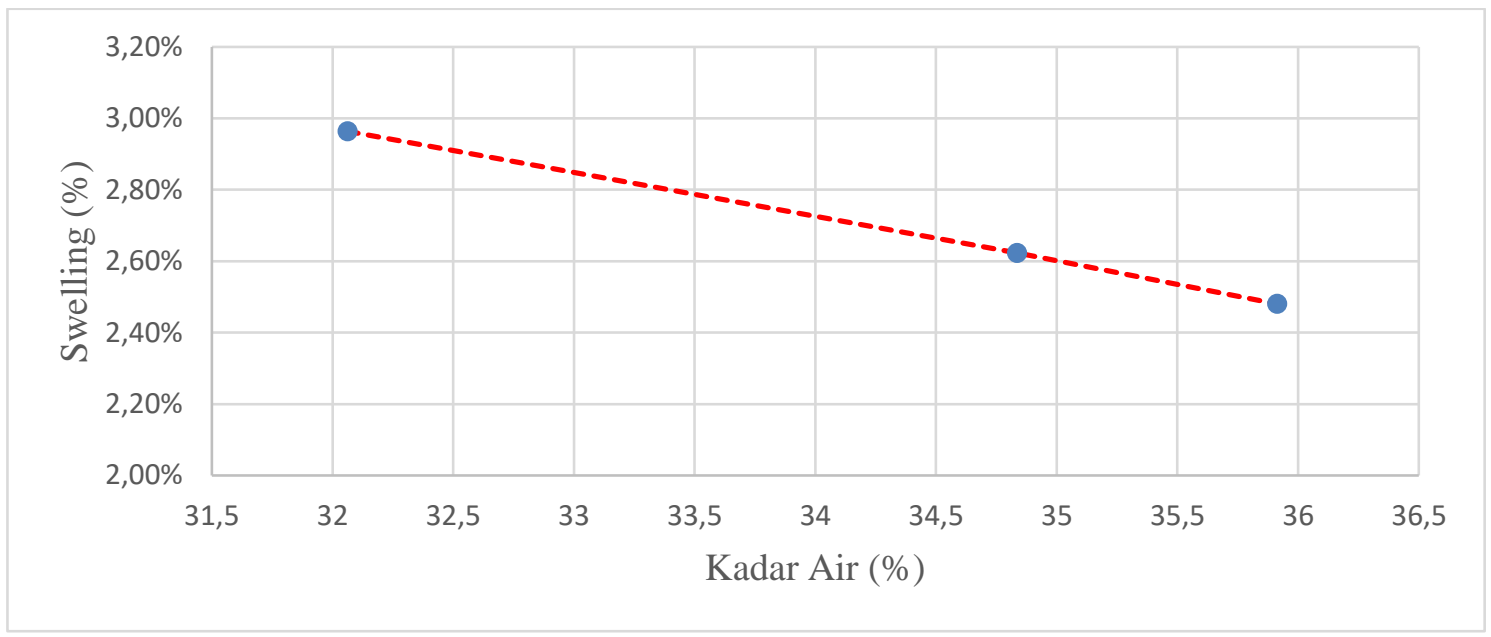

Gambar 11. Grafik nilai pengembangan tanah dengan terhadap penambahan kadar air 